\title{
LVII. On the maritime commerce of Bengal
}

\section{Anthony Lambert Esq.}

To cite this article: Anthony Lambert Esq. (1805) LVII. On the maritime commerce of Bengal , Philosophical Magazine Series 1, 21:84, 327-343, DOI: 10.1080/14786440508676727

To link to this article: http://dx.doi.org/10.1080/14786440508676727

\section{Published online: 18 May 2009.}

Submit your article to this journal $x$

LII Article views: 4

Q View related articles $\asymp$ 
Fig. 2. (Plate V.) A highly magnified representation of the parasitic plant which infects the wheat: $a$ in a young state; $b$ full grown; $c$ are two plants bursting and shedding their seeds when under water in the microscope; $\boldsymbol{d}$ two plants burst in a dry state; $e$ seems to be abortive; $f$ seeds in a dry state; $g$ a small part of the bottom of a pore with some of the parasitic fungi growing upon it.

Fig. 3. A part of the straw of fig. 1. magnified.

Fig. 4. Part of fig. 3. at $a b$ more magnified.

Fig. 5. Part of a straw similar to fig. 3 . but in its green state, and before the parasitic plant is quite ripe.

Fig. 6. A small part of the same, more magnified.

Fig. 7. (Plate VI.) A highly magnified transverse cutting of the straw, corresponding with fig. 4 . showing the insertion of the parasite in the bark of the straw.

Fig. 8. A longitudinal cutting of the same; magnified to the same degree.

Fig. 9. A small piece of the epidermis of a straw, showing the large pores which receive the seed of the parasite; the smaller spots observable on the epidermis, are the bases of hairs that grow on the plant of the wheat whilst young, but which fall off when it ripens, magnified to the same degree as the preceding figures.

\section{On the Maritime Commerce of Bengal. By the late AnTHONy LamberT, Esq.*}

To treat fully of objects so important, and of such magnitude, would require a range of information and accuracy of eletail, which can only be expected from great practical experience, aided by the most liberal communieations from the public offices of government, in their commercial, revenue, and marine departments. The records of the customhouse are in most countries, except Bengal, open to the inspection of individuals; but this source of information being inaccessible to us, the amount of foreign trade must be assumed from other data.

Although Bengal possesses a considerable extent of sea coast, (from the Subunreecka to the Rajoo river, about $\mathbf{3 4 0}$ miles,) she has but few good harbours; her situation, nevertheless, is well adapted for foreign commerce. Occupying an intermediate station in that vast portion of the

* From the Asiatic Ammal Register for 1803 . 
globe usually denominated the East Indies, her aecess is rendered easy to the remotest shores of Africa, Asia, and America.

On the west, and contiguous to Bengal, lies the great peninsula of Hindustan. To the numerous ports and settlemente on both coasts of this peninsula, particularly the coast of Coromandel, Bengal carries on a constant, extensive, and profitable commerce, which may properly be called her home, or coasting trade. On the east she borders on Assam, and touches the dominions of Ava. The former she supplies exclusively with salt; and from the latter receives all her teak timber for ship building and domestic use. The bay of Bengal, embracing the west end of Sumatra, and washing the coast of Malaya, affords a direct communication through the straits of Malacca to China and the eastern isles, where the opium, saltpetre, and piece goods of Bengal are always in great demand. With the Persian and Arabian gulfs, as well as the eastern coast of Africa, Bengal likewise maintains commercial intercourse, though many obstacles have in late years supervened, to impede her commerce in that quarter.

Calcutta, the political and commercial capital of British India, as well as the emporium of Bengal, is situated on the Houghly river, or western branch of the Ganges, about 100 miles from the sea, and accessible to ships of all sizes at all seasons. From Calcutta, foreign imports are transported with great facility by the Ganges and its subsidiary streams to the northern nations of Hindustan; and the consumption and exports of Calcutta are readily supplied through the nunerous rivers which intersect Bengal in every direction, and to which her prosperity has been ascribed, not only as they facilitate communication and conveyance, but likewise as they contribute to the fertility of her soil.

The elegant villas that adorn the banks of the Houghly, and the southern aspect of Calcutta, impress the mind of a stranger, on his approach, with high ideas of the opulence of this great city; but the shipping that crowd the port point out to him the true source of its splendor. Numerous and magnificent houses, erected within a few years, are undoubted proofs of prosperity, and the great population and extent of the place (still rapidly increasing), with the busy and animated operations of the harbour, indicate an active and thriving commerce. I am happy to yield my unqualified assent to this observation; and it is with no small degree of national pride, that I can safely ascribe, in 
a great measure, these beneficial effects to the spirited exertions of British merchants resident in India. Exclusive of the company's exports, it is to their individual efforts that Bengal owes her shipping and her commerce.

In tracing the rise and progress of the maritime trade of Bengal, since it fell under the sway of Great Britain, I cannot, for want of materials, extend my researches further back than the year 1773 . The accompanying abstract, compiled from the port list of arrivals and departures, will show the number and the tonntge of vessels which have imported and cleared out from Calcutta, or the river Houghly, for the years $1773,1783,1791,1792,1793$, and 1794, distinguishing the nations to which they belong, or whose colours they assume : and annexed thereto will be found a statement for the years 1783 and 1793, showing the different ports from whence the ships of those years arrived, and those to which they were bound.

My intention in compiling this abstract is to show the rapid increase of the maritime commeree- of Bengal since the year 1783; and more especially the increase of the country trade, or that which is carried on to and from ports in India. I stall confine my observations principally to the years 1783 and 1793 : the former, the first year of peace after the American war; and the latter, the year when the present war commenced, intelligence of which reached Bengal on the 4 th of June.

In 1773 , the reader will perceive that only 160 sail of vessels entered the port, whose aggregate burthen was 44,497 tons ; and no more than 108 vessels, carrying 33,470 tons, cleared out : of the former, 102 sail, burthen 28,872 tons, were country ships, under English colours; and of the latter 95 sail, burthen 25,080 tons, were of the same description. Ten years afterwards, at the close of the American war, we find the tonnage inward increased to 64,510 tons, on 149 vessels; and the departures were 114 sail, carrying 49,225 tons. But this increase was only apparent; for, the war having detained an unusual number of the compary's ships in India, it will be perceived that they constitute a large proportion of the arrivals and departures of that year, many of them being employed in carrying stores to the different presidencies, and in the coasting trade : to these must be added transports and men of war. The country shipping under English colours, which arrived and sailed in 1785, only amounts to 128 sail, carrying 44,865 tons; whereas in 1773 their numbers were 190 , and burthen 53,052 tons; which exhibits a decline of this 
tonnage, in consequence of the war, in the proportion of one-fifth nearly; and we are persuaded that the captures made by the enemy during that unfortunate contest, might be stated at a much larger proportion.

Our fleets in India, in that disastrous period, although numerous, powerful, and well appointed, afforded but little protection to the commerce of the country. Not a single frigate, in my recollection, was ever detached as a convoy to merchant ships in the country trade: nay, I have heard it frequently asserted, that ships of war, sailing from Bengal to join the fleet on the coast of Coromandel, have rejected all applications for protection to merchantmen pursuing the same voyage; notwithstanding they were laden with grain for the supply of our armies in the Carnatic, where famine was then raging with all its horrors. I am not competent to say how far the detention of a frigate a few days, for the purpose of a convoy, might have been injurious to the public service; but the merchants here, in the loss of property, and the famished inhabitants of the coast, in the privation of food, felt severely this inattention to trade, and complained bitterly on the occasion. Nor did they fail to observe, that, for other scrvices, that which did not appear to them of any importance to the public: welfare, but undertaken solely for the purpose of acquiring prize money, frigates and sloops of war were readily detached. Smarting under repeated and heavy losses, they could, neither perceive the utility nor applaud the zeal which prompted the aid of a frigate and sloop of war to assist this government in the reduction of the defenceless Dutch factory at Chinsurah in 1781, the capture of which afterwards furnished a subject of so much litigation.

The daring activity of $\mathbf{M}$. Suffrein at this juncture made a striking impression. No change of monsoon induced him to quit the bay of Bengal; and during the absence of our fleet, in their annual visit to Bombay for refitment, and to avoid the storms that prevail at the autumnal equinox, he swept the seas, destroyed our trade, and intercepted the supplies from tisis to the other presidencies. A ship of the line and two frigates, which he stationed off the Sand Heads, or entrance into the Houghly, at one time nearly shut up the port, at another made many valuable captures, carrying hack an ample supply of all sorts of provisions and stores, which nither his own resources, nor those of his allies, could have furnished. From the abundance of Bengal both friends and foes drew their supplies; and, however much the loss of what fell into the enemy's hands might have 
been regretted, it was a fortunate circumstance, that, during the whole of that war, from a succession of favourable crops, the great exports of grain created no enhancement of price; or, at least, tot greater than is experienced in the ordinary fluctuations of the market.

We shall pass over the years 1791 and 1792 without further observation, than to remark, that from 17:3 to 1791, the general trade of Bengal had increased from 13,735 tons, the total of arrivals and departures in the former year, to 244,035 tons of shipping, which imported and cleared out in the latter; and that the English country shipping, which cleared in and out, had risen from 128 sail, carrying 44,865 tons, to 575 sail, burthen 175,407 tons; by which it appears that the country trade, in the course of only eight years, had multiplied near four-fold. The effect of this astonishing increase of maritime trade on the general prosperity of the country, will be readily perceived and admitted.

I come now to the year 1793, when the present war originated, which soon after the commencement here became ruinous in the extreme to the trade of this country. Intelligence of hostilities reached us in June, when the only English ship of force in India was the Minerva frigate: she left the Indian seas in the month of February 1794, and, until the arrival of commodore Newcombe off the Mauritius in May following, the whole of the British commerce and possessions in this quarter of the globe was without the protection of a single ship belonging to the British navy. Thirteen sail of frigates and privateers, which sailed from the Mauritius, captured, besides two Indiamen, numbers of the most valuable ships in the country trade; and would speedily have annihilated our commerce, and shut up every port in India belonging to us and our allies, had they not been checked by the vigour of the supreme government. Our present governor-general, with a promptitude and decision which does honour to his administration, equipped and dispatched a squadron from Bengal, consisting of three armed Indiamen and a country ship, strengthened by a detachment of artillery and troops from the garrison, which captured two of the enemy's privateers, and repulsed an attack made by their grand armament under M. Renaud; obliging him soon after to return to the Mauritius, without effecting any further mischief than the capture of the Pigot Indiaman. Some notice of these circumstances seemed necessary to explain the sudden. decline of trade in 1794: that any commerce was continued, 
nued, is due to the exertions of the supreme government for its protection.

In 1793, we find the tonnage inward and outward to consist of 757 vessels, burthens 291,190 tons ; and of these 575 were English country ships, carrying 209,279 tons. In 1794 , the total of arrivals and departures was reduced to 441 sail, burtben 163,484 tons; of which 286 were English country ships, carrying 96,391 tons; so that the general trade of the port, since the commencement of the present war, has decreased 127,706 tons, and the Indian trade on British ships 112,948 tons, being a declension of more than ane-half of the country trade.

The documents from which the foregoing statements bave been draxin, are, as we have already mentioned, the port lists of arrivals and departures, which are registered in the master attendant's office, and may be received as accurate, so far as they extend, with respect to number. But we cannot say so much as to tonnage, for there being no tonnage duties paid here, the ships are never measured, and their burthen is of course estimated, or taken from the information of the commander. Nor does this list exhibit wuch vessels as are piloted by native pilots or by their own commanders, which is the case with the native craft; or vessels belonging to and navigated by natives from the northern circars on the coast of Coromandel.

It is also much the practice with native commanders of other vessels outward bound to save the pilotage charged by the company's pilots, which, on ships drawing much water, falls very heavy, particularly on vessels sailing under foregn colours. To estimate, therefore, the maritime commerce of Bengal fr om these documents, particularly the exports, would be to undervalue it greatly. We lament the want of better materials ; but taking them as an occasional guide, and referring to such other sources of information as we have been able to procure, we shall attempt to form some general idea of its magnitude, and the channels through which it flows.

The exports to Europe and to the United States of Ameriea, in importance and extent constitute by far the most considerable portion of the cominerce of Bengal. They may be comprised under the general heads of cotton and silk wrought and unwrought, sugar, drugs, and dyes, including indigo and saltpetre. As the medium adopted for the remittance of the surplus revenues of these provinces, the company's investment occupies the greatest share in this trade, being unquestionably the most valuable. 
In No. 15 of the Appendix to the Report of the Committee of Accounts, published by the court of directors in February 1799, we find an account of the prime cost of all the cargoes purchased by the company in India for five years, from 1786 to 1791 inclusive. We shall only state the last year's investment for Bengal, or that provided for 1790-1, as we believe it has rather been increased since that period; and we shall adopt that as the present amount of the company's exports from Bengal, being 99,11,598 current rupees, or 1,06,00,109 current rupees, including commercial charges at $6,88,511$ current rupees. The private trade laden on the company's ships by individuals is estimated by the directors, on an average of three years prior to 1793 , at 300 tohs, and valued in England at 6941. pet ton, making 208,2001 ., the prime cost of which may be taken, on a conjectural estimate, at 15 lacks of current rupees; to this must be added the value of goods laden on the privileged tonnage of the commanders and officers of the company's ships. Fifty tons are allowed to each ship of 755 tons and upwards; and a further priviiege of 30 tons is allowed, provided no goods ordered to be laden on the company account are refused. We will suppose that $\mathbf{5 0}$ tons only are occupied; and, estimating the number of ships on an average of 15 per annum, give us 750 tons for the whole privileged tonnage. It is to be remarked, that all the ships which arrive at Bengal generally fill up their privilege at this place, although they may be afterwards destined to Madras, Bencoolen, or other ports in India ; and as the company have lately increased their tonnage to this port, we presume the number of tons we have allowed for privilege is less than what is really occupied*. This tonnage we value at 3000 current rupees per.ton, making $22 \frac{1}{2}$ lack of current rupees, or about 15,00ol. for each ship. Had we estimated the value of privileged tonnage at 20,000 l. per ship, we should probably have approached nearer to the truth; for it is the medium by which the captains and officers remit home the proceeds of their outward adventures; and those who have no adventures sell their privilege to others.

\footnotetext{
* Fourteen company's ships sailed from Bengal in the season 1793-4 for Madras, Bencoolen, and Europe, and three on a cruise for the protection of trade. In 1794-5 the number dispatched was twenty-three, including those ships that were employed as cruizers, and exclusive of six small ships not in the regular line of the service, which were sent out to be laden with sugar.
} 
It is curious to observe the various modes by which com merce is pursued, and the expedients which are adopted for mutual advantage. For some years past it has not been the practice with the captains and officers of the company's ships to fill up their own privileged tonnage, or but a portion of it; and yet they convert it into a profitable and safe remittance for the proceeds of their adventures to this country. Little skilled in Indian goods, and of course liable to imposition, they have wisely abandoned the bomeward adventure to merchants resident in Bengal, who fill up their privilege, receive their money, and grant bills, at the rate of $2 \mathrm{~s} .4 \mathrm{~d}$. to $2 \mathrm{~s}$. $6 \mathrm{~d}$. for the current rupee. In the exchange is included freight and insurance, and it depends on the value remitted per tan, whether the freight is dear or cheap. The less the merchant draws for, the cheaper he obtains his freight; for the exchange may at least be reckoned 20 per cent. beyond par, which of course becomes a charge for freight and insurance. The bills are paid from the proceeds of the goods, and if the ship is lost, the obligation of payment is void.

In estimating the value of exports to Europe and America on foreign ships, we shall form our calculation from the tonnage cleared out in the last three years, 1792, 1793, and 1794. It may be objected to this estimate, that two of the years we have selected being a period of war, neutral tonnage under foreign flagg would be increased. This, no doubt, has some influence; but the war having involved every nation in Europe, except the Danes and Swedes, although we have had an increase of Danish ships in consequence thereof, other foreign tomnagc has declined in a greater proportion. Taking, then, the departures of foreign ships for Europe and America in 1790, we find them to consist of

\begin{tabular}{llllr}
7 Ships under French colour & - & - & Tons Bur. \\
1,410 \\
1 Dutch ditto & - & - & - & 200 \\
4 Danish ditto & - & - & - & 2,300 \\
3 Portuguese ditto & - & - & - & 1,400 \\
1 Imperial ditto & - & - & - & 730 \\
5 Genioese ditto & - & - & - & 2,280 \\
16 American ditto & - & - & - & 4,302 \\
\hline & & & & 13,622 \\
\hline
\end{tabular}


For 1793.

Tons Bur.

3 Ships under French colours - - 2,000

6 Danish ditto

1 Portuguese ditto

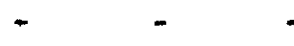

- 3,150

5 Genoese ditto

21 American ditto

For 1794 .

21 American ditto

14 Ships under Danish colours

$-\quad-$

6,297

3 Portuguese ditto

6 American* ditto

$$
14,717
$$

The medium of the three years gives 12,963 tons; but as many of the ships under foreign colours from Europe and America, touch at intermediate ports in. India, and are therefore recorded as arriving from or sailing to an Indian port, they must be added to the ships which tonade a direct voyage. In the years before mentioned, these departures were as follows :

$$
\begin{aligned}
& \text { In 1792, } 27 \text { vessels, carrying - } 6,880 \text { tons. } \\
& 1793,28 \text { ditto - } \quad 9,355 \\
& 1794,11 \text { ditto } \quad \text { - } 2,200 \\
& 18,635
\end{aligned}
$$

The medium is $6,211 \frac{2}{3}$ tons per annum.

The proportion of the cargoes of these ships intended for the Europe market, it would be impossible to ascertain: we shall estimate it at one-sixth of the medium for three

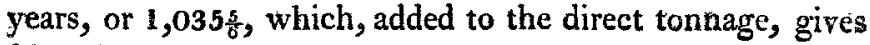
13,998.5 tons.

As a considerable portion of tonnage is occupied by gruff goods, we cannot estimate it higher than 1000 current rupees, or $100 l$. per ton: even at this rate the whole value will amount to current rupees $1,39,98,833,54$, to which adding the exports on the company's ships, the total of goods exported to Europe and America amounts by this computation to two crores, eighty-three lacks, forty-eight thousand nine hundred and forty-two current rupees, five

- The American tonnage declined this year, from a very general apprehension that prevailed here, of the United States beconing a party in the presept war. 
annas, four pice, or $2,834,894 ; 481$. $4 \mathrm{~s}$. $8 \mathrm{~d}$. The Dutch company, whose trade from Bengal was formerly so considerable, that, within our recollection, their exports to Europe exceeded forty lacks per annum, have not, to our knowledge, provided any investment for Europe for several years past; we must therefore exclude them for the present from our estimate of Europe exports, and proceed to the country trade.

That branch of it which first claims our attention, is the intercourse with our settlements, and the different ports on the coast of Coromandel in its greatest extent, including the Northern Circars, and reckoning from Point Palmiras to Cape Comorin; which we have already denominated the home trade.

This trade, as will be perceived from the port lists, gives employ to the greatest portion of our home tonnage; and is important, not only for its nature and extent, but for the constant resource which it affords to our shipping, of moderate freights, on grain, when other employments fail, or at intervals when they must otherwise remain idle.

The principal articles of export to Madras and the coast of Coromandel are grain and pulse, sugar, saltpetre, molasses, ginger, long pepper, clarified butter, oil, silk wrought and unwrought, muslins, spirits, provisions, \&ec.

In the year 1793,234 ships, burthen 84,045 tons, cleared out for the coast of Coromandel; and of this tonnage we suppose that $1,033 \frac{1}{2}$ tons were filled by goods intended for Europe, and 80,000 tons at least were occupied by grain and pulse; which, valued on a medium at two and a half current rupees per bag of two bazar maunds, or $164 \mathrm{lb}$. avoirdupois, when shipped, and 13 bags to the ton, amounts to 26 lacks of rupees. Other exports to this coast on shipping owned by European traders, are estimated at 8 lacks, making in the whole 34 lacks of current rupes. But the advantages of this traffic must not be appreciated by the value of the goods when shipped, but their value when sold; for the freight of grain is nearly equal to the cost ; and, if we take the sales, on a medium of five current rupees per bag, or allow for freight and charges two and a half curreni rupees, we find it to he a trade which pays to the European shipping of India near twenty-seven lacks of current rupees per annum. To this must be added the exports on donies and native craft, or vessels belonging to and wholly navigated by natives of India. Before the prohibition of foreign salt their number was very considerable, particularly from the Northern Circars; but that measure 
depriving them of a freight of salt to Bengal, and having nothing to substitute but money for their purchases, it operated for many years as a severe check on this branch of trade. A more liberal policy was adopted by lord Cornwallis, by drawing part of the annual supply of salt from the coast, which, with many other advantages, affoided considerable encouragement both to native and European shipping. Since that period this trade has begun to revive, and we may now rate the tonnage of vessels belonging to and navigated by natives, which annually visit Bengal, from all quarters, including the Maldivian vessels, and those from the coast of Malabar and Muscat, at 10,000 tons. Their exports are principally grain and pulse, with some coarse sugar, long pepper, ginger, and silk and cotton piece goods, which may be estimated at about five lacks of current rupees; and, added to the exports for this coast on ships navigated by or belonging to Europeans, make 39 lacks of current rupees.

After the Coromandel trade, we place that to the eastward, and China; and, were our scale of precedence determined by the capital it employs, exclusive of shipping, or, in other words, by the value of its exports only, it would stand next in rank to that of Europe: but we cannot hold any branch of trade which requires a capital of fifty-five lacks of rupees, and an outlay of twelve months, to give employment to 11,000 tons of shipping, equal to that which employs 84,000 tons on a capital of thirty-four lacks only, and which returns the outlay in eight or ten weeks.

The grand article which supports the eastern trade is opium. This fascinating drug has ever been in great request amongst all eastern nations, but more particularly among the Malays. In its oblivious fume (for they generally smoke it) they find refuge from every care and anxiety; and, when the evils of life press beyond their powers of endurance, taken in another form, it excites the devoted wretch to deeds of horror and destruction.

Amongst this sanguinary people, all ranks and ages, who have the means of procuring it, use opium without restraint; and the Chinese, notwithstanding it is prohibited by their laws under severe penalties, appear to be equally fond of the drug. It was formerly difficult to import opium into China, and the quantity sold there was trifling; but, in defiance of prohibitory laws, the consumption of China cannot now be rated at less than half the quantity. exported from Bengal.

By the company's sales for the year 1793-4, it appears that 4,520 chests of Patna opium were delivered to the Vol.21. No. 84. May 1805. Y Dutch 
Dutch and Danes, and 450 chests were sold, and produced $28,87,780$ sicca rupees; besides which 700 chests sent, or the company's account, to Bencoolen and Prince of Wales's Island. These 1,150 chests, valued at the medium rate of the sales of Patna opium, amount to $6,36,668,12$ sicca rupees. To this must be added about 500 chests annually imported from Oude, which, estimated at 500 rupees per chest, makes the whole amount to $32,74,448$ sicca rupees, or $37,98,359$ current rupees. Nearly the whole of this is exported to the eastern islands and China; or, if we deduct two lacks for home consumption (which we know to be principally supplied by smuggled opium), and allow. D8,358 108 rupees for occasional exports to the coast of Coromandel and Malabar, we shall not over-rate the value of this article exported to the eastward, in stating it at 35 lacks of current rupees. Besides opium, our traders carry to the eastward and China, grain, saltpetre, gumpowder, iron, fire-arms, cotton, wool, silk, and cottin piece goods, \&c.; of the latter, inclading what goes to Manilla and Batavia, the value is considerable; not less, in our opinion, than ten lacks of rupees. If I estimate all other articles at five lacks, the exports amount to fifty-five lacks; and I do not conceive my assumption of the value of eastern exports will be found overcharged.

Next to the eastern trade I place that to Bombay and the ports on the Malabar coast, including Surat, which, in the year 1793 , occupied 51 vessels, carrying 28,100 tons. Of this tonnage, I think, no less than 25,000 tons consisted of grain and pulse, which, taken at the former valuation of two and a half current rupees per bag, gives $8,12,500$ current rupees. Other articles of export to these marts consist principally of sugar, raw silk, some silk and cotton piece goods, saltpetre, ginger, long pepper, sacking (called gunnies), hempen rope, \&c., which do not exceed five or six lacks of rupees; and the wbole exports miay be reckoned at 14 lacks of current rupees.

To the gulfs of Arabia and Persia, Bengal sends grain, suggar, silk and cotton piece goods, \&c. This trade was formerly so considerable, that the annual returns were estimated at thirty lacks of rupees; but, owing to the anarchy which has prevailed in Persia since the death of Kherim Khan, the successor of Nadir Shah, and in Egypt, since the overthrow of Ali Bey, with a variety of other causes, it has greatly declined of late years $;$; and including the eastern coast

* It has been confidently asserted that the trade to Sucz was shut ap 
of Africa, the Maldives; and Mauritius, we cannot estimate the exports at more than eight lacks of mpees.

Notwithstanding the large quantity of teak timber annually imported from Pegue, the balance of trade is much in favour of Bengal. Her exports to the douninions of the king of Ava, including Arractn; consist chiefly of silk and cotton piece goods, fire-arms, iron, nails, naval and military stores, and a variety of European goods; which may be estimated at about six lacks of current rupees.

It remains to be noticed, the supplies to the new settlement on the Andanans, occasional cargoes to the colonies at Port Jackson, in New Holland, and expeditions to the north-west coast of America and Kamschatka: these cannot be rated beyond two lacks per annum.

Combining all the exports by sea under the heads to which we have referred them, they appear as follow:

Europe and America

Curr. Rupees.

2,83,48,942 54

Madras and coast of Coromandel - $\quad 39,00,000$

Eastern islands, Malay coast, and China - $55,00,000$

Bombay, Surat, and sther ports on the Malabar

coast - - - - 14,00,000

Gulfs of Persia, to Arabia, eastern coast of

Africd, Maldives and Mauritius - - $8,00,000$

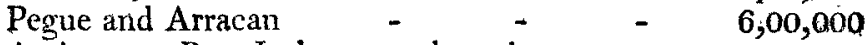

Andamans, Port Jackson, and north-west coast

of America

To this sum should be added exports by land to the Decan, Thibet, Nepaul, and the various nations that surround Bengal; but of these, although considerable, we can form no computation. We know, however, that in the year 1791 there was exported from Benares alone, to the Decan and Mahratta states, above a lack of maunds of sugar by inland traders, and the quantities of raw and wrought silks, and piece goods, with a variety of European goods, which are annually purchased by inland merchants, amount to a considerable sum; probably not less than an eighth part of

by the Porte in consequence of representations made by our ambassador to the Ottoman government, at the instance of the court of directors. A measure so injurious to Bengal we cannot attribute to those who are bound to cherish and support her; pnlicy and humanity would prompt a different conduct. We must therefore suppose the prohibition arose from the xasura! jealousy of the Turkish government. 
the exports by sea, Was I, therefore, to rate the whole annual exports of Bengal, by sea and land, at four millions and $a$ half of pounds sterling, $J$ should, in my own opinion, form a moderate estimate of their value.

Imperfect as the materials are from which I have drawn my computation of the export trade of Bengal, I am sorry to confess, that I am withoul any guide whatsoever to direct me in forming the most distant idea of the amount of imports. Had I even access to the records of the customhouse, they would afford very unsatisfactory grounds from which any conclusions could be drawi.

The company's imports pay no duty. Some of the foreign ships discharge their cargoes at Serampore, which of course pay no duty to the company, and do not appear on the books of the custom-house; and smuggling is a plant which rears its head in every climate, I shall not, therefore, hazard any estimates on this head, for all that I conld offer would be only vague conjecture. Since the abolition of government customs, no duties have been levied at $\mathrm{Cal}-$ cutta on exports. Foreigu and inland imports pay four per cent. ad valorem, with an exception to indigo, and to silk and cotton piece goods of the produce of the country; the former paying no duty, and the latter only two per cent. The duties on liquors are fixed at so much per dozen, or gallon. A new regulation, I am informed, is about to take place, which frees inland imports from all duty, and im-s poses two and a half per cerit. on all imports by sea, and the same on exports. This regulation will increase the port duties, without being unfavourable to the trade of the country, inasmuch as the whole consumption of inland produce in Calcutta is thereby liberated ; for we cannot estimate the impost on goods cxported, including even the advanced price, or the profits of the intermediate merchant, who buys from the manufacturer or inland trader, and sells to the foreign exporter at a sum equal to the amonnt of the present duties on inland imposts into Calcutta, which comprehend as well the consumption of the place as the exports therefrom.

Provided the different articles of import and export be precisely enumerated at the custom-house, and this source of information is accessible, the regulation will afford to fiture speculators on this subject some better data than we possess for estimating the amount of the trade of Bengal.

The imports of Bengal may be classed under the same general heads into which we have divided the exports. From Europe she receives metals of all sorts, wrought and unwrought, 
wrought, woollens of various kinds, naval and military stores of every description, gold and silver coin and bullion; and almost every article of the produce of Europe, which people in affluent circumstances there consume, is imported for the use of the European inhabitants.

The returns from Madras and the coast of Coromandel consist of salt, red wond, some fine long cloth, izarees, and chintz, and occasional speculations of European goods, or the produce of other countries previously imported there. The balance due to Bengal is either absorbed by drafts or bills on this government, drawn by the Madras presideney, $o l$ is remitted in specie.

From the eastern islands and Malay coast are received pepper, tin, wax, dammer, brimstone, gold dust, specie, betel-nut, spices, benzoin, \&c. : from China, tutenag, sugar-candy, tea, alum, dammer, porcelain, and lackered ware, and a variety of manufactured goods : and from $\mathrm{Ma}-$ nilla, indigo of a very fine quality, (which is re-exported to Europe, sugar, japan wood, and specie. The balance of this trade, meaning the whole eastern commerce, is generally paid into the company's treasury at Canton for bills on the conrt of directors, (which are negotiated here, and, whilst the exchange was at 5s. 6d. for the Spanish dollar, formed an advantageous remittance,) or it is absorbed by bills granted by the treders to this government, and payable to the supereargoes in China.

The Malabar coast pays ber purchases with sandal wood, coyar rope, pepper, some cardamums, and occasional cargoes of cotton wool: the balance is remitted by bills, or surik in the annual supplies which Bengal furnishes to the presidency of Bombay.

From Pegue are brought teak timber, tin, wax, elephants' teeth, lac, \&c. The gulfs make their returns in coffee, specie, brimstone, dates, and some other articles of inconsiderable value. And the Maldives and eastern coast of Africa supply cowries and coyar. 
On the Maritime Commerce of Bengal.

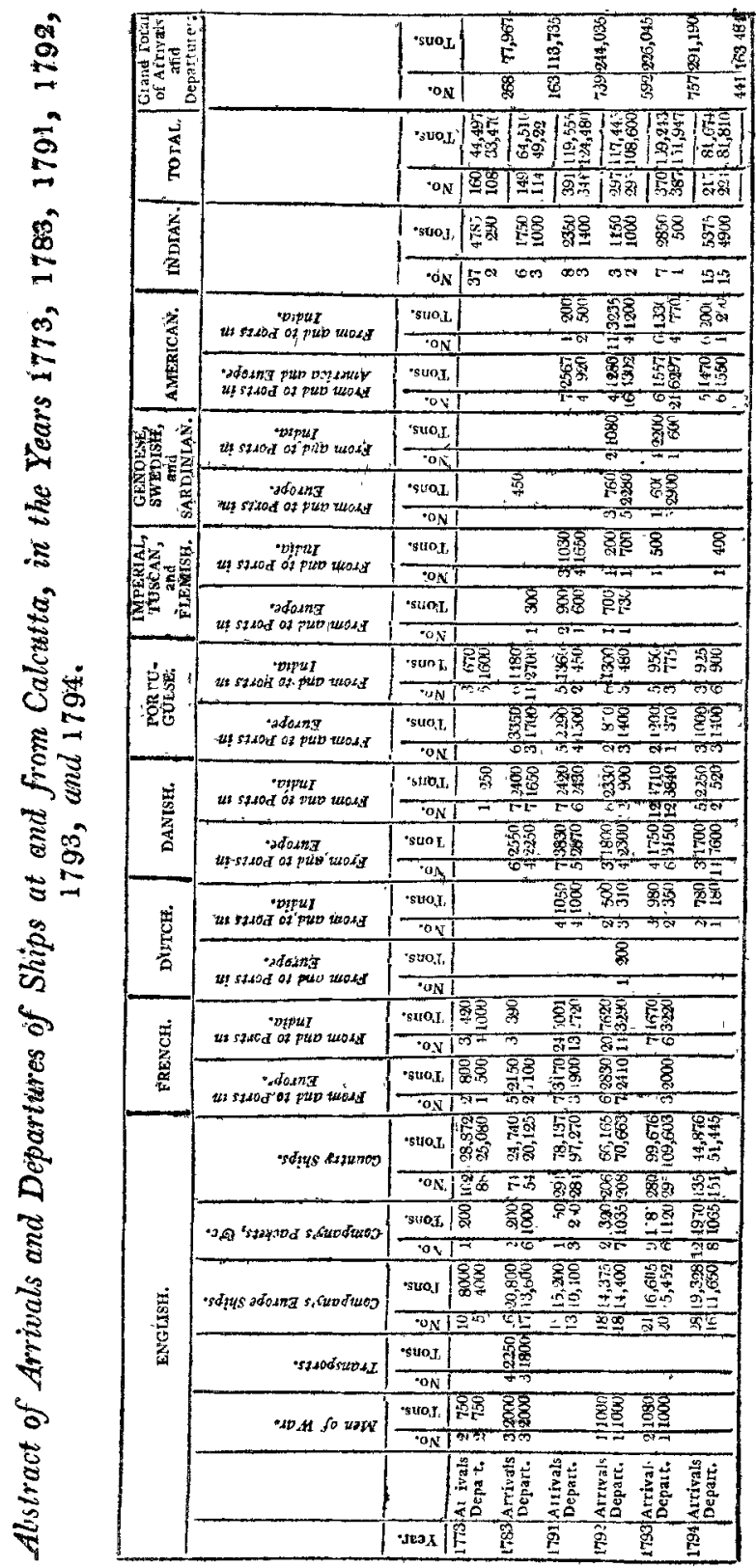


On the Maritime Commerce of Bengal.

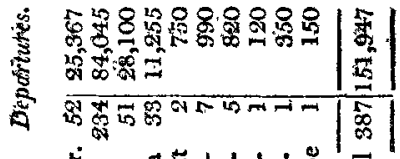

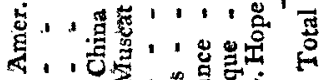

9

$=1$

is

远些

\& $\infty$

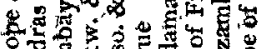

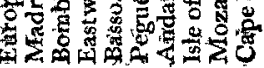

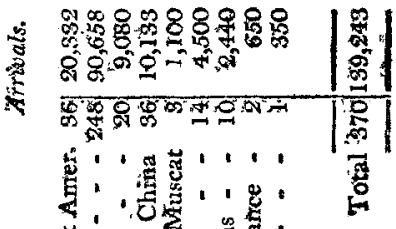

28

蒿

领

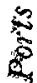

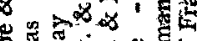

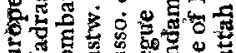

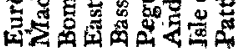

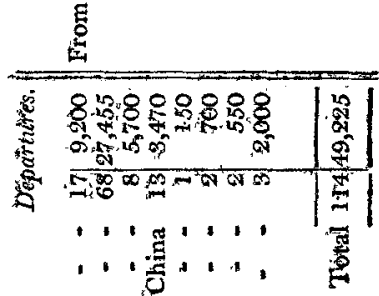

-

।

地

है

胥

हैं

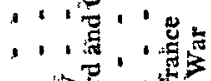

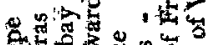

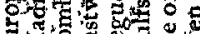

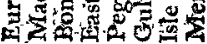

$\stackrel{\circ}{1}$

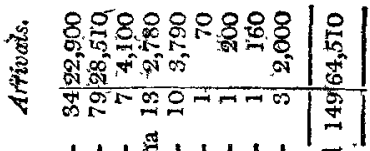

1. 1. $11.1,1$.

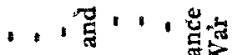

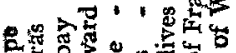

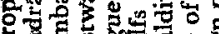

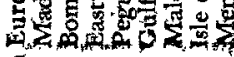

ह

LVIII. $A n$ 